\title{
Sistem Elektronik untuk Refreshable Braille dengan Fitur Suara dan Integrasi dengan Android
}

\author{
Edy Hamid Saifullah, Tasripan, dan Hendra Kusuma \\ Departemen Teknik Elektro, Fakultas Teknologi Elektro, Institut Teknologi Sepuluh Nopember (ITS) \\ e-mail: hendraks@ee.its.ac.id
}

\begin{abstract}
Abstrak-Salah satu media informasi yang dapat digunakan oleh penyandang kesulitan melihat adalah refreshable braille display yang merupakan perangkat yang dapat menampilkan karakter braille secara dinamis dan bisa berubah sesuai dengan perintah yang diberikan oleh penggunanya. Di Indonesia, refreshable braille display masih belum ada dipasaran sehingga untuk memperolehnya harus memesan ke luar negeri. Berdasarkan informasi pada situs delysid.org, untuk mendapatkan refreshable braille display yang terdiri dari 24 sel, harus mengeluarkan biaya sekitar 3600 euro atau setara dengan sekitar 53 juta rupiah. Padahal, penyandang tunanetra, khususnya di Indonesia, kebanyakan berasal dari kalangan menengah kebawah sehingga harga tersebut kurang terjangkau. Berangkat dari masalah diatas, dibuatlah sebuah inovasi yaitu refreshable braille dengan fitur suara dan integrasi dengan perangkat android dimana alat ini dirancang memiliki 14 sel huruf braille. Dalam tugas akhir ini, akan dibuat suatu sistem elektronik yang dapat mengakomodir seluruh 14 sel huruf refreshable braille serta fitur-fitur lain yang disematkan. Sistem ini kemudian diuji dengan hasil dapat memunculkan pola-pola braille sebanyak 7 sel dengan error rate rata-rata $6,48 \%$ pada fitur navigasi dan integrasi dengan perangkat android. Selanjutnya, harga komponen habis pakai mencapai 3.4\% dari harga alat yang dijadikan patokan dalam penelitian ini. Fitur suara tidak dapat dioperasikan karena terjadi kesalahan pada pemilihan perangkat keras.
\end{abstract}

Kata Kunci-Refreshable Braille, Sistem, Fitur.

\section{PENDAHULUAN}

$\mathrm{T}$ EKNOLOGI informasi dan komunikasi saat ini telah mendigitalisasi hampir di setiap aspek kehidupan manusia. Jual beli, interaksi sosial, birokrasi pemerintahan, dan tidak terkecuali teknologi pembelajaran. Media pembelajaran yang turut mendapatkan dampak dari teknologi informasi dan komunikasi adalah media pembelajaran untuk penyandang tunanetra. Kemajuan teknologi elektronika telah memberikan pilihan media pembelajaran baru bagi penyandang tunanetra dalam sebuah pembelajaran.

Salah satu media yang dapat digunakan oleh penyandang tuna netra dalam mencapai informasi adalah refreshable braille display. Media ini merupakan perangkat yang dapat menampilkan karakter braille secara dinamis dan bisa berubah sesuai dengan perintah yang diberikan oleh penggunanya [1]. Di Indonesia, apabila ingin mendapatkan perangkat refreshable braille display yang terdiri dari 24 sel seperti pada Gambar 1.1, harus mengeluarkan biaya sekitar 3600 euro atau setara dengan sekitar 53 juta rupiah [2]. Padahal, penyandang tunanetra, khususnya di Indonesia, kebanyakan berasal dari kalangan menengah kebawah sehingga harga tersebut harus memesan dari luar negeri karena belum jamak tersedia di pasaran. Dilansir dari situs delysid.org tahun 2016, untuk mendapatkan refreshable braille display yang terdiri dari 24 sel seperti pada Gambar 1.1, harus mengeluarkan biaya sekitar 3600 euro atau setara dengan sekitar 53 juta rupiah [2]. Padahal, penyandang tunanetra, khususnya di Indonesia, kebanyakan berasal dari kalangan menengah kebawah sehingga harga tersebut tidak terjangkau.

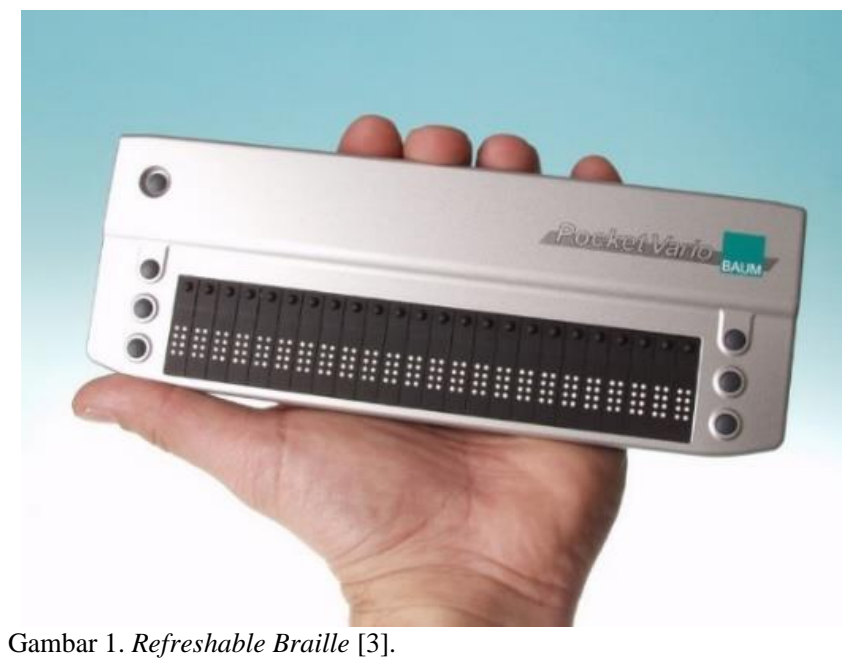

Pada penelitian ini akan dibuat sebuah perangkat yang menggunakan metode refreshable braille yang dapat difungsikan sebagai media informasi bagi tunanetra khususnya untuk belajar membaca dan mengenali huruf braille. Perangkat ini nantinya akan dilengkapi juga dengan fitur suara mengingat suara juga merupakan salah satu media informasi utama bagi penyandang tunanetra. Kemudian sebagai fasilitas pendukung, disematkan fitur integrasi dengan perangkat android supaya orangtua atau pengajar dapat turut serta dalam proses pembelajaran.

Namun, dengan penyematan fitur-fitur kompleks diatas tentunya membutuhkan suatu sistem elektronik yang kompleks pula. Kompleksitas tersebut diantaranya adalah pembuatan driver yang sesuai dengan jumlah sel, pemilihan modul kontrol utama yang mumpuni, serta komponenkomponen tambahan lain yang capable untuk mengakomodir segala keperluan penggunaan alat. Untuk itu, dalam tugas akhir ini, dirancang sebuah sistem kendali elektronik yang dapat mengakomodir fitur-fitur yang ada pada perangkat refreshable braille dengan fitur suara dan integrasi dengan perangkat android. Sistem tersebut haruslah dapat menjalankan fitur-fitur perangkat dengan baik sehingga fungsionalitas perangkat refreshable braille dapat maksimal. 


\section{LANDASAN TEORI}

\section{A. Sistem Huruf Braille}

Sistem tulisan Braille mencapai taraf kesempurnaan di tahun 1834 [4]. Huruf-huruf Braille menggunakan kerangka penulisan seperti kartu domino. Satuan dasar dari sistem tulisan ini disebut sel Braille, di mana tiap sel terdiri dari enam titik timbul yaitu tiga baris dengan dua titik. Keenam titik tersebut dapat disusun sedemikian rupa hingga menciptakan 64 macam kombinasi. Huruf Braille dibaca dari kiri ke kanan dan dapat melambangkan abjad, tanda baca, angka, tanda musik, simbol matematika dan lainnya. Ukuran huruf Braille yang umum digunakan adalah dengan tinggi sepanjang $0,5 \mathrm{~mm}$, serta spasi horizontal dan vertikal antar titik dalam sel sebesar $2,5 \mathrm{~mm}$.

\begin{tabular}{|c|c|c|c|c|c|c|c|c|c|c|c|c|c|c|c|}
\hline & $\because$ & $\bullet$ & (9) & $\because$ & $\because$ & : &. & : : & $::$ : & $\therefore$ & .. & . &.. & 9 & $0^{\circ}$ \\
\hline & & & 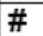 & $\$$ & $\%$ & $\&$ & & & & & + & & & & \\
\hline & $\bullet$ & $:$ & $\bullet$ & $\because$ & $\theta$ & $\because:$ & :: & : & $\because$ & $\because$ & : & $\because$ & :: & 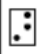 & 婙 \\
\hline & 1 & 2 & 3 & 4 & 5 & 6 & & 8 & $\mathrm{~S}$ & & & $<$ & $=$ & $>$ & $?$ \\
\hline & 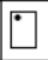 & : & $\because$ & $\because$ & $\because$ & 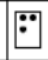 & $\because$ & $\therefore$ & $\theta^{\circ}$ & $\because:$ & $\because$ & $\vdots$ & $\because$ & $\because: 0$ & $\because$ \\
\hline @ & $\mathrm{A}$ & $B$ & C & D & $E$ & $F$ & $G$ & $\mathrm{H}$ & 1 & $\mathrm{~J}$ & $\mathrm{~K}$ & $\mathrm{~L}$ & $M$ & $\mathrm{~N}$ & 0 \\
\hline & $::$ & $: 0$ & $:^{\circ}$ & $:$ & .. & : & $\because:$ & 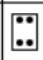 & : & $::$ & $\because$ & $\because$ & $:$ & 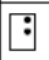 & : \\
\hline & $Q$ & & $S$ & $\bar{T}$ & $\mathrm{U}$ & V & $W$ & $X$ & $Y$ & $Z$ & & 1 & & & \\
\hline
\end{tabular}

Gambar 2. Huruf Braille [5].

Braille terdiri dari sel yang mempunyai 6 titik timbul yang dinomorkan seperti berikut dan kehadiran atau ketiadaan titik itu akan memberi kode untuk simbol tersebut. Huruf Braille Bahasa Melayu adalah hampir sama dengan kode huruf Braille Inggris. Perkataan, simbol (seperti tanda seru dan tanda soal), beberapa perkataan dan suku kata bisa didapat secara terus. Contohnya, perkataan orang disingkat menjadi org. Ini membolehkan buku Braille yang lebih tipis dicetak.

\section{B. Printer Braille}

Salah satu metode dalam menulis braille adalah menggunakan printer braille. Printer ini akan secara otomatis mencetak huruf-huruf abjad menjadi huruf-huruf braille dengan prinsip mirip dengan penggunaan reglet braille dan stylusnya. Printer ini berbeda dengan printer pada umumnya karena tidak menggunakan tinta melainkan menggunakan sebaris stylus. Prinsip pencetakan ini sebenarnya mirip dengan prinsip pencetakan kertas dengan menggunakan dot matriks. Salah satu printer braille bernama Braillo Norway 400s Seri 3. Printer ini, sesuai dengan namanya berasal dari Norwegia sehingga pengadaannya di Indonesia perlu mengimpor terlebih dahulu.

Penggunaan printer ini pada dasarnya mirip dengan penggunaan printer teks pada umumnya. Namun kertas yang dipakai lebih tebal dan tentunya lebih mahal. Dokumen sebelumnya telah disiapkan menggunakan perangkat Personal Computer yang kemudian dikirimkan datanya ke printer braille. Printer ini akan secara otomatis mecetak pola-pola braille pada kertas sesuai dengan abjad yang telah dibuat.

\section{Baum Vario 340}

Baum Vario 340 merupakan produk dan layanan untuk tunanetra. Perangkat ini merupakan refreshable braille display dengan tampilan braille yang ringkas untuk rumah maupun di kantor. Vario 340 adalah penampil braille 40 sel berkualitas tinggi namun tetap terjangkau untuk pengguna komputer yang membutuhkan alat yang ringkas dan ringan untuk digunakan dengan komputer di rumah, kerja, atau sekolah.

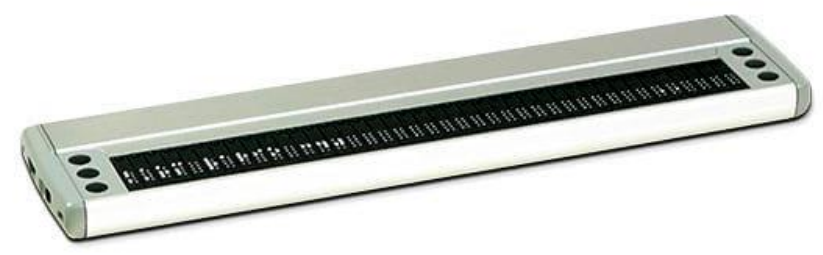

Gambar 3. Baum Vario 340

Seperti tampilan braille BAUM lainnya, Vario 340 adalah Human Interface Device (HID), yang berarti tidak perlu menginstall driver untuk menggunakannya. Vario 340 memiliki port USB Tipe C, yang berarti akan sangat memudahkan pemasangan karena tidak masalah kearah mana USB menghadap. Berikut adalah spesifikasi Baum Vario 340.

1. Mudah dan nyaman digunakan.

2. Human Interface Device (HID).

3. Port USB Tipe $\mathrm{C}$ baru.

4. 40 sel braille dengan perutean kursor terintegrasi.

5. Tombol fungsi praktis.

6. Build quality yang bagus.

\section{Orange Pi Zero}

Orange Pi Zero merupakan sebuah komputer papan tunggal opensource yang dapat menjalankan sistem operasi Ubuntu, Android 4.4, dan Debian [6]. Orange Pi Zero menggunakan AllWinner H3 SoC dan memiliki 256MB DDR3 RAM. Papan Orange Pi Zero merupakan sebuah mini komputer yang memiliki performa layaknya komputer namun dengan dimensi serta konsumsi daya yang relatif kecil.

Sesuai dengan sebutannya sebagai mini komputer, Orange Pi Zero juga memiliki port-port ekspansi standar komputer. Port-port tersebut diantaranya adalah USB 2.0, LAN, Stereo Audio, TV-Out, USB OTG dan 17 low peripheral pin yang dapat difungsikan sebagai GPIO. Kesemua pin-pin ini dapat dijalankan fungsinya secara bersamaan atau biasa disebut dengan multitasking.

\section{E. Shift Register (SN74HC595)}

Kompen SN74HC595 adalah sebuah IC jenis SIPO (Serial Input Paralel Output) 8-bit. Didalam IC ini terdapat rangkaian flip-flop tipe D yang juga memiliki besar 8-bit yang mana mendapatkan sinyal dari shift register diatas. Register penyimpan bit data dari IC ini memiliki 3 kondisi output (3-state output) yang disambungkan secara parallel. Shift Register pada IC ini memiliki pin SRCLR yang berfungsi sebagai pereset utama apabila active low. Kemudian pin SER sebagai pin input data. Selanjutnya terdapat pula pin output-enable (OE) yang apabila pada kondisi high, maka output IC berada pada kondisi highimpedance.

SN74HC595 memiliki beberapa jenis kemasan yang tersedia di pasaran. Salah satu jenis kemasan yang dapat dipilih adalah kemasan SOP (Small Outline Package). Komponen-komponen dengan kemasan ini sering disebut dengan komonen SMD (Small Mounted Device) karena pada 
pengaplikasiannya, komponen ini disolder sebidang dengan jalur tembaga pada papan sirkuit. Meskipun memiliki dimensi yang jauh berbeda dengan kemasan lain, misal kemasan DIP (Dual Inline Package), fungsi kerja serta spesifikasi elektrisnya dapat dikatakan identik.

\section{F. Shift Register (SN74HC595)}

Komponen-komponen induktif pada umumnya membutuhkan daya yang relatif besar agar dapat beroperasi. Salah satu contohnya adalah komponen relay. Selain membutuhkan daya yang relatif besar, komponen tersebut juga menimbulkan permasalahan lain, yaitu munculnya arus flyback yang dapat merusak komponen-komponen sensitif utamanya transistor. Hal ini membuat komponen relay tidak dapat dioperasikan secara langsung oleh pin-pin output dari mikrokontroller.

Pengoperasian relay melalui kendali mikrokontroller membutuhkan suatu komponen tambahan berupa driver. Salah satu komponen driver yang dapat digunakan adalah IC ULN2003. Komponen tersebut pada dasarnya adalah saklar digital dengan basis susunan transistor darlington (Darlington Transistor Array) berlumlah 7. ULN2003 dapat mengalirkan arus kolektor-emittor sebesar maksimum 500 $\mathrm{mA}$ [7], jumlah yang cukup untuk mengoperasikan relay 5 volt ttl.

ULN2003A memiliki beberapa jenis kemasan yang tersedia di pasaran. Salah satu jenis kemasan yang dapat dipilih adalah kemasan SOP (Small Outline Package). Komponen-komponen dengan kemasan ini sering disebut dengan komonen SMD (Small Mounted Device) karena pada pengaplikasiannya, komponen ini disolder sebidang dengan jalur tembaga pada papan sirkuit. Berikut ilustrasi spesifikasi dimensi dari ULN2003A.

\section{PERENCANAAN DAN PERANCANGAN SISTEM}

\section{A. Analisa Spesifikasi Modul Mekanik}

Modul mekanik adalah komponen utama / fungsi utama dari perangkat refreshable braille ini. Komponen yang dipakai dalam pembuatan perangkat ini merupakan kombinasi antara komponen elektromagnetik dan pengungkit yang pada ujung lengan pengungkitnya dikopel dengan tactile braille (yang selanjutnya disebut pin-pin braille). Kombinasi antara komponen elektromagnetik dan pengungkit ini memiliki karakteristik elektrik yang mirip, atau bisa dikatakan sama dengan karakteristik komponen relay sinyal kecil (low signal). Selanjutnya, komponen mekanik ini disusun sedemikian rupa sehingga dapat membentuk suatu sel braille. Berikut ilustrasi perancangan modul mekanikya.

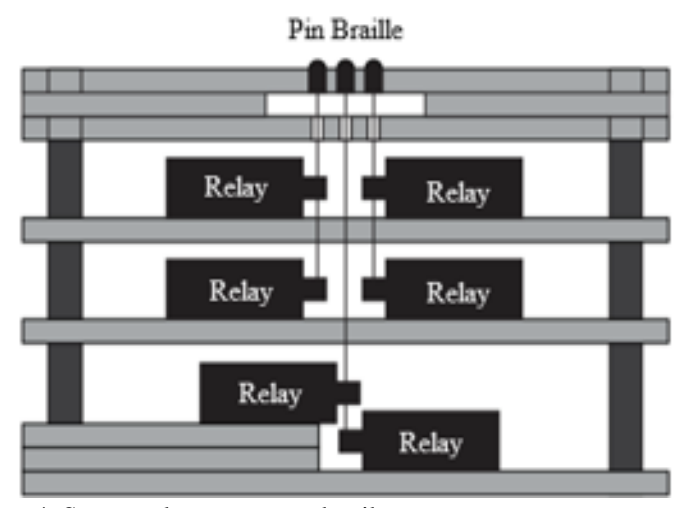

Gambar 4. Susunan komponen mekanik.
Komponen ini dapat aktif pada tegangan 5 volt dan dengan arus sekitar 0.028 ampere. Sehingga, pada perancangan driver nantinya dapat dianalogikan sebagai komponen relay.

\section{B. Analisa Kebutuhan Penggunaan Alat}

Pada bagian ini, dianalisis kebutuhan penggunaan alat yang telah ditetapkan seblumnya. Adapun tujuan dari analisis ini adalah untuk menentukan peralatan apa saja yang dibutuhkan dalam pembuatan sistem elektronik. Adapun kasus penggunaan alat dapat dilihat pada Gambar berikut ini.

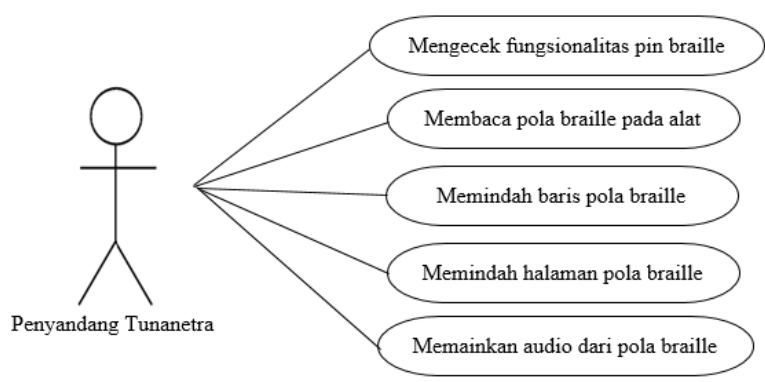

Gambar 5. Diagram kasus penggunaan terhadap alat.

Pada analisis kasus penggunaan diatas, dapat diuraikan bagaimana sistem elektronik akan dibangun. Berikut uraiannya :

1. Mengecek fungsionalitas pin braille

Mengecek disini berkaitan erat dengan kasus penggunaan nomor 5. Ini berarti bahwa pin-pin braille yang muncul harus sesuai dengan data suara yang dihasilkan oleh alat.

2. Membaca pola braille pada alat

Modul mekanik yang telah dibuat sudah tervalidasi dapat dibaca dengan baik. Tantangan yang muncul untuk pembuatan sistem elektronik adalah bagaimana sistem yang dibuat harus dapat menangani fungsionalitas dari modul ini dan tidak sampai harus mengubah komposisi dari modul yang menjadi fitur utama dari perangkat refreshable braille ini.

3. Memindah baris pola braille

Memindah baris pola braille adalah suatu fitur untuk menampilkan pola-pola braille sesuai dengan data yang diinginkan. Tentunya data ini telah disimpan secara digital didalam perangkat refreshable braille ini. Maksud dari memindah baris ini adalah menavigasi kemunculan pola-pola pada modul mekanik supaya membntuk huruf-huruf abjad pada suatu file / halaman. Kemunculan atau pola-pola braille yang pertama kali terbentuk adalah pola yang membentuk susunan huruf "aaaaaaa". Kemudian apabila dinavigasi ke baris selanjutnya, maka baris yang muncul adalah "bbbbbbb" dan baris seterusnya sampai pada akhir dokumen. Selanjutnya, semisal pola yang muncul adalah pada baris ke 3, yaitu "ccccccc" maka apabila dinavigasi kembali ke baris sebelumnya, maka baris yang muncul adalah "bbbbbbb" dan seterusnya sampai pada baris pertama.

4. Memindah halaman pola braille

Memindah halaman pola braille adalah suatu fitur untuk menampilkan pola-pola braille sesuai dengan data halaman yang diinginkan. Tentunya, sama seperti kasus penggunaan memindah baris, data ini telah 
disimpan secara digital didalam perangkat refreshable braille ini. Maksud dari memindah halaman ini adalah menavigasi kemunculan pola-pola pada modul mekanik supaya membentuk huruf-huruf abjad sesuai dengan halaman yang ditunjuk.

Kemunculan atau pola-pola braille yang pertama kali terbentuk adalah pola yang membentuk susunan huruf "aaaaaaa" pada halaman pertama. Kemudian apabila dinavigasi ke halaman selanjutnya maka baris yang muncul adalah "abcdefg", yaitu baris pertama pada file / halaman selanjutnya. Begitu seterusnya sampai pada file / halaman terakhir yang telah tersimpan pada memori alat. Selanjutnya, semisal pola yang muncul saat ini adalah pada halaman ke 3 baris pertama, yaitu "inibudi" maka apabila dinavigasi kembali ke halaman sebelumnya, maka baris yang muncul adalah "abcdefg" dan seterusnya sampai pada file / halaman pertama dari file yang telah tersimpan.

5. Memainkan audio pada pola braille

Audio yang dimainkan pada kasus penggunaan ini adalah audio yang telah direkam sesuai dengan data baris huruf yang telah ditentukan sebelumnya. Misal, telah diinputkan file suara dengan bunyi "INI BUDI", maka apabila muncul pola yang sesuai dengan pola tersebut diatas, maka alat akan mengeluarkan bunyi "INI BUDI".

\section{Perancangan Driver}

Driver pada perangkat refreshable braille dengan fitur suara dan integrasi dengan perangkat android dibuat berdasarkan 2 kebutuhan. Pertama adalah kebutuhan mengenai port ekspansi dari modul pemroses utama, yaitu Orange Pi Zero. Konfigurasi pin Orange Pi Zero hanya memiliki 17 pin yang dapat difungsikan sebagai GPIO. Hal ini praktis membuat Orange $\mathrm{Pi}$ Zero tidak dapat mengakomodir seluruh pin-pin braille pada komponen mekanik yang berjumlah $14 \times 6$ pin (6 pin tiap sel, total 14 sel). Untuk itu, perlu adanya penambahan komponen yang dapat difungsikan sebagai perluasan output dari pin-pin GPIO dari modul mini pc Oange Pi Zero ini.

Pin-pin yang berfungsi sebagai GPIO dari Orange Pi Zero berjumlah 17 pin. Maka dari itu, dipilihlah suatu komponen Serial Input Paralel Output sebagai perluasan dari GPIO Orange Pi Zero ini. Komponen IC yang dipilih adalah SN74HC595. Dengan penggunaan IC 74HC595 ini, sangat dimungkinkan untuk penambahan jumlah sel-sel huruf braille pada pengembangan selanjutnya tanpa harus mengubah konfigurasi penempatan GPIO pada Orange $\mathrm{Pi}$ Zero.

Shift Register pada IC SN74HC595 menerima data serial dari unit pemroses. Data yang diterima adalah 3 jenis, yaitu sinyal clock oleh STCP, sinyal data oleh SHCP, dan sinyal enable oleh ENA. Sebaris sinyal data yang dikirimkan secara serial diterima melalui pin SHCP. Sinyal ini akan membuat register untuk pin QA bernilai high atau low. Penerjemahan kondisi sinyal SHCP pada register QA terjadi saat sinyal yang diterima oleh STCP pada kondisi high ke low atau lebih dikenal pada kondisi falling-edge. Kemudian, nilai bit yang telah disimpan pada register QA akan dimunculkan di pin QA ketika ENA menerima sinyal low. Pada clock selanjutnya, nilai bit pada register QA ini akan digeser ke register QB yang juga akan digeser ke register QC pada clock seterusnya. Ketika sinyal yang pada awalnya "milik" QA telah mencapai QG, pada clock selanjutnya sinyal ini akan digeser ke QH yang juga akan menjadi sinyal milik QH'. Nah, sinyal QH' inilah yang akan disambungkan ke pin SHCP pada IC berikutnya sehingga data-data dari modul pemroses utama dapat didistribusikan sampai pada IC terakhir yang disematkan pada perangkat. Proses shifting nilai bit dari modul pemroses utama dapat dilihat pada timing diagram berikut.

\section{Perancangan Papan Terintegrasi}

Papan terintegrasi sebenarnya adalah sebuah papan extender untuk pin-pin dari modul Orange $\mathrm{Pi}$ Zero. Pembuatan papan terintegrasi memiliki tujuan utama untuk meminimalisir penggunaan kabel sebagai penghubung antara satu komponen dengan komponen lainnya. Pada rancangan papan terintegrasi ini, disematkan sebanyak mungkin komponen maupun modul-modul elektronik untuk maksimalisasi penggunaan ruang didalam casing yang telah dibuat. Komponen komponen tersebut diantaranya adalah port-port ekspansi, modul OrangePi Zero, modul regulator tegangan, komponen buffer sinyal, serta komponenkomponen pendukung lain yang dibutuhkan. Skema dari papan terintegrasi dapat dilihat pada gambar berikut ini.

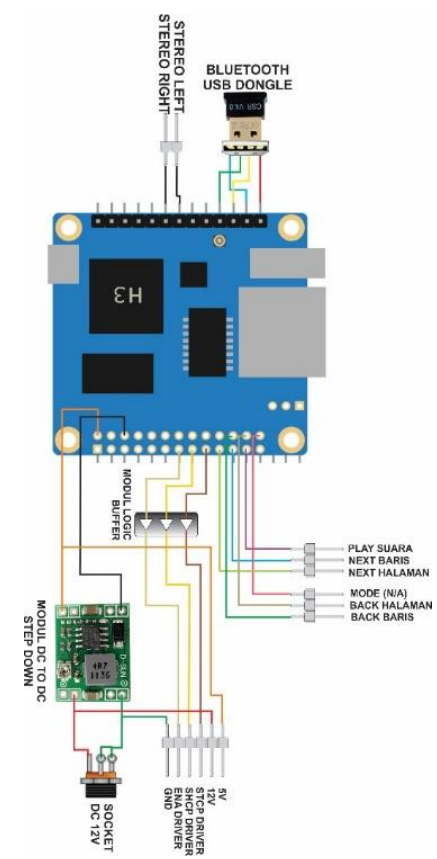

Gambar 5. Skema papan terintegrasi.

Selanjutnya dari skema yang telah dirancang, dibuatlah suatu papan sirkuit (Printed Circuit Board) sebagai bentuk implementasi perancangan. PCB yang dibuat menggunakan model double layer yang mana antar kedua layer dihubungkan dengan metode trough hole. Pada rancangan ini, lebar PCB yang dapat dicapai adalah $45 \mathrm{~mm}$ sedangkan panjangnya adalah $86 \mathrm{~mm}$.

\section{PENGUJIAN SISTEM}

\section{A. Pengujian Fitur Next Baris}

Pengujian pertama adalah fitur next baris pada dokumen. Perlakuan yang diberikan kepada perangkat dalam pengujian ini adalah dengan memencet tombol next baris sampai akhir isi dokumen. Dokumen yang dipakai pada pengujian ini berisi 26 baris dimana pada setiap baris berisi 7 huruf dengan abjad yang sama. 
Tabel 1.

Uji Ketepatan Display Next Baris

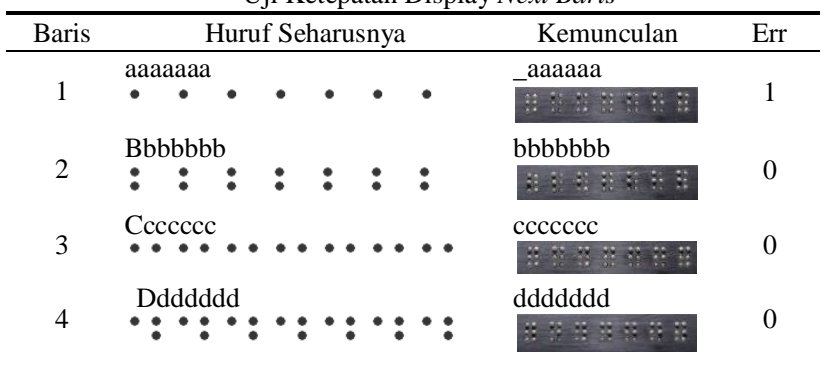

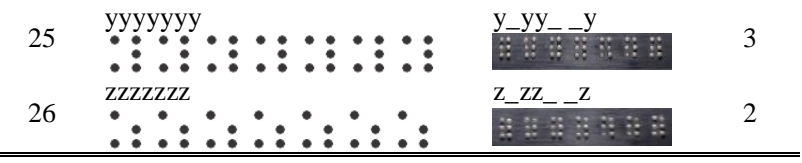

Dari pengujian, dapat diamati bahwa error yang terjadi adalah $7,14 \%$ dengan perhitungan adalah sebagai berikut :

$$
\begin{aligned}
& \text { Error }=\frac{\text { Jumlah Error Keseluruhan }}{\text { Jumlah Sel } \times \text { Jumlah Uji }} \times 100 \% \\
& \text { Error }=\frac{13}{7 \times 26} \times 100 \% \\
& \text { Error }=7.14 \%
\end{aligned}
$$

\section{B. Pengujian Konektivitas Bluetooth}

Uji konektivitas Bluetooth dilakukan dengan cara menyambungkan perangkat dengan android via Bluetooth. Kemudian setelah pairing sukses, dilakukan pengiriman karakter secara acak untuk menguji ketepatan tampilan refreshable braille pada kemungkinan-kemungkinan susunan karakter yang diinputkan pengguna aplikasi. (Tabel 2)

Pada pengujian konektivitas Bluetooth, dapat diamati bahwa sedikit sekali terjadi error. Error muncul pada pengujian ke-8 dan ke-9. Pada pengujian ke-1 sampai ke-8, display refreshable braille dapat menampilkan pola-pola braille dengan baik. Adapun kesalahan yang terjadi pada pengujian ke- 8 dan ke-9, terjadi karena adanya pin braille penyusun huruf yang gagal muncul.

\section{Pengujian Fitur Suara}

Uji fitur suara dilaksanakan dengan menekan tombol play suara kemudian didengarkan secara langsung kualitas suara yang dihasilkan. Dari pengujian dapat diamati bahwa suara tidak dapat muncul sesuai dengan yang diinginkan. Suara yang muncul ketika diteka tombol play suara hanyalah suara mendesis selama beberapa detik. Namun, durasi desisan sama dengan durasi suara yang ingin ditampilkan. Hal ini berarti terdapat kesalahn dalam memainkan audio pada sisi amplifier.

\section{Estimasi Biaya Pembuatan}

Biaya yang dibutuhkan didasarkan pada harga komponen saat artikel ini ditulis. Tujuan dari penghitungan biaya adalah sebagai pembanding dengan harga alat refreshable braille yang telah ada di pasaran. Keseluruhan biaya yang dihitung belum mencangkup biaya fixed cost peralatan produksi, tenaga kerja, pemasaran dan pajak. Sehingga nilai akhir yang muncul merupakan harga bahan alat murni.

Total harga yang didapatkan adalah Rp.1.814.000. Angka ini tentu masih cukup jauh jika dibandingkan dengan nilai 3600 euro atau sekitar 53 juta rupiah. apabila dikalkulasi, maka biaya habis pakai oleh alat hanya mencapai $3.4 \%$.
Tabel 2.

Uji Ketepatan Display Konektivitas Bluetooth

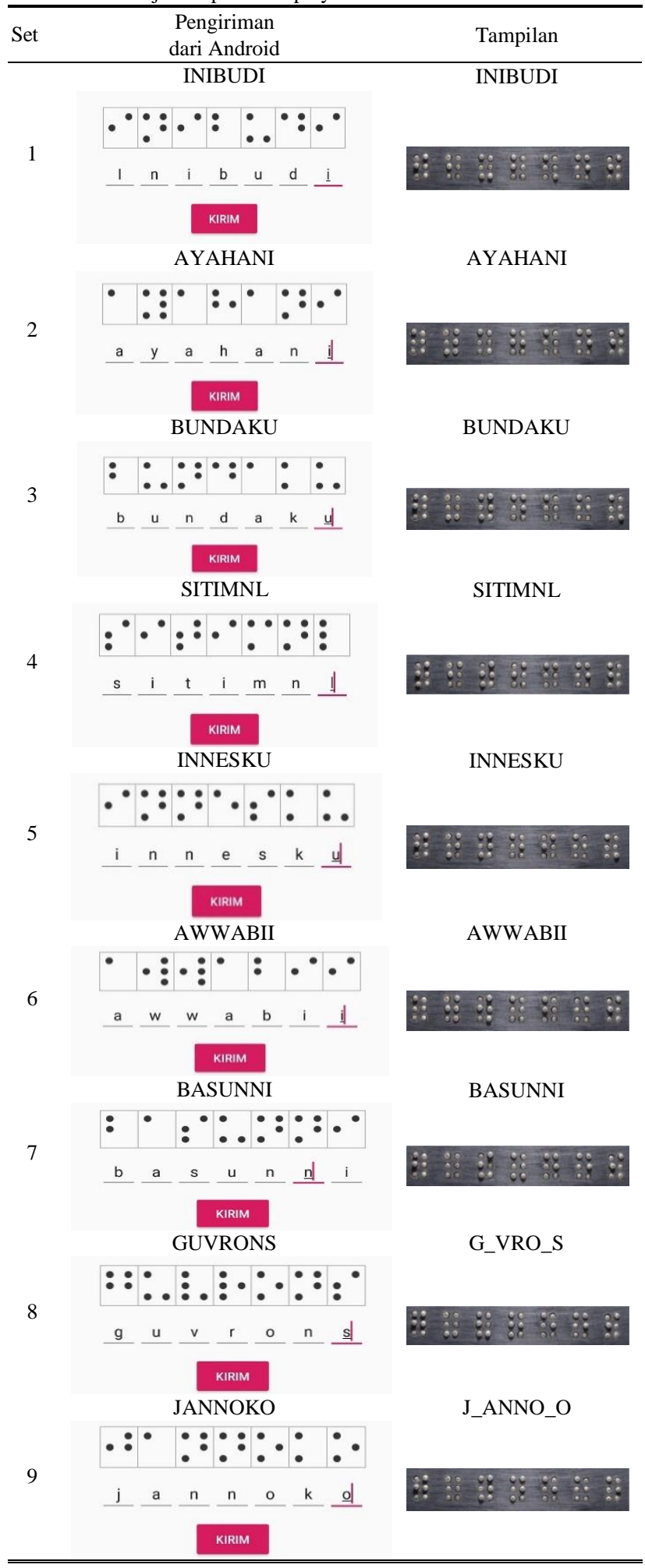

\section{KESIMPULAN}

Berdasarkan analisa data yang dilakukan pada bab sebelumnya, dapat ditarik kesimpulan sebagai berikut:

1. Modul tombol sebagai navigasi fitur dapat berfungsi dengan baik.

2. Konektivitas dengan perangkat android melalui media Bluetooth dapat berfungsi dengan baik.

3. Tidak terjadi kesalahan interpretasi data pada modul mekanik, kesalahan display terjadi karena terdapat pinpin mekanik yang tidak berfungsi. 
4. Speaker tidak dapat mengeluarkan suara dengan baik ketika fitur ini daktifkan melalui tombol play suara.

\section{DAFTAR PUSTAKA}

[1] Anonymous, "Situasi Penyandang Disabilitas," Jakarta, 2004

[2] Badan Pusat Statistik, "Indonesia - Sensus Penduduk 2010,' Jakarta, 2010.

[3] A. Diono, "Buletin Jendela Data \& Informasi Kesehatan,"
Jakarta, 2014

[4] V. Kartha and et al, DRISHTI-A Gesture Controlled Text to Braille Converter. Thiruvananthapuram, 2012

[5] A. Kulkarni and K. Bhurchandi, Low Cost E-Book Reading Device for Blind People. Nagpur, 2015.

[6] Orange Pi Zero, "What's Orange Pi Zero,"www.orangepi-.org, 2018.

[7] Texas Instrument, "ULN200x, ULQ200x High-Voltage, HighCurrent Darlington Transistor Arrays," 1976. 